\title{
Danuta Walczak-Duraj
}

University of Lodz

Faculty of Economics and Sociology

Department of Sociology of Politics and Morality

e-mail: Danuta.duraj@uni.lodz.pl

\section{Causes of deficits and ethical dilemmas in scientific research*}

\begin{abstract}
The analysis of the deficits and ethical dilemmas in research will be related to two disciplines of the social sciences: sociology and economics. Research conducted within these disciplines, because of its multi-paradigm nature, tends to be characterized by deficits, not only ethical but also ethical and methodological dilemmas and interpretation reasons. The leading thesis of this paper aims to argue that the looming deficits and ethical dilemmas of Polish researchers in the field of social sciences are two basic but very different premises.

The first group of reasons primarily refers to broad ethical deficits, perceived unreliableness in terms of scientific research. It is related mainly to the structural aspects of the functioning of universities and other research units and logic parameterization. In the ethical programs (especially codes of ethics), ethical deficits are identified in three areas of "activity" of research related to the description, diagnosis and interpretation of the results relating to: bragging - e.g. the preparation, recording and publishing of the results that were not obtained; falsificationwhich means manipulating the research materials, equipment or method, replacing or bypassing the data in such a way that the results are not presented in a true way; plagiarism - the appropriation of other people ideas, methods, results, or terms without proper reference. Plagiarism is also the unauthorized use of information obtained through confidential review of proposals and manuscripts, or e.g. using conference presentations without permission. Its structural evidence is primarily the emphasis on "productivity" and parameterization as the basic criterion, not only of scientific but also academic success-oriented and personalized careers.
\end{abstract}

\footnotetext{
* The article is an updated version of the paper published in Polish in the Annales. Ethics in Economic Life, 20(1), 17-32.
} 
The second group of reasons refers primarily to broad ethical dilemmas; to the ethical context of social research at every stage of the proceedings: conceptualization, selection of methods, techniques and research tools, conducting research (which concern, for example, the covert participant observation), analysis and interpretation of data, publishing developed and interpreted empirical material. Performing even a cursory analysis of how to present research findings in these two disciplines, you can come to the conclusion that the methodological competence of the investigator does not always go hand in hand with ethical competence. What is more, there is a tendency to downplay the principle that the social sciences should be guided by the principle of the so-called humanistic coefficient.

Keywords: deficits and ethical dilemmas, research, multi-paradigm approach of social sciences

JEL Classification: I23

\section{Introduction}

From the Higher Education Development Program until 2020, adopted by the Plenary Assembly of Conference of Rectors of Academic Schools in Poland on April 26, 2013, it follows that Polish universities occupy quite distant positions in international research rankings, while Polish science as a whole is almost unnoticeable on the international arena. Poland also has the worst scientific publication coefficient in the region per one hundred thousand inhabitants, while the increasing rate of the number of scientific works per one academic teacher results directly from the shrinking human resources of higher education (Woźnicki, 2015, p. 8). What is more, even a cursory review of media publications - including electronic ones, ${ }^{1}$ it is a sufficient basis for perceiving the ethical condition of the Polish scientific community as unsatisfactory. The reasons for this situation are very complex and cannot be reduced only to quite obvious, as in any professional environment, ethical deficits of specific people. It is obvious that when we undertake scientific research, regardless of the field or discipline, we must always - to a lesser or greater extent - take into account their ethical context. Regardless of the legal and procedural solutions adopted, it refers to the determination of ethical standards to be followed by both researchers themselves and those who collect and evoke empirical data subjected to subsequent aggregation actions. The ethical context is determined first of all by referring to temporal and cultural conditions, and very intrinsically complex conditions referring to the ethical disposition (sensitivity) (cf., among others, Kopka, 2000), ethical self-awareness (cf., among oth-

\footnotetext{
${ }^{1}$ Etyka i patologie polskiego środowiska akademickiego, https://ntaetyka.cordpress.com/category/aspe kty-finase/page $3 /$.
} 
ers, Liberkowski, 2009; Walczak, 2010), ethical knowledge (Reykowski, 1990, pp. 14-18) and even resentment of the researcher, understood in Scheler's (1977) terms.

The aim of the considerations undertaken in this text is to characterize the deficits and ethical dilemmas most often encountered during the implementation of scientific research in general, and scientific research in two disciplinessociology and economics - in particular. Ethical dilemmas are understood here, above all, as a synonym of moral dilemmas experienced by the individual in the situation of the necessity of making a difficult choice between two or more situations, possibilities or solutions whose consequences, to a greater or lesser extent, are connected with bearing moral responsibility. When we talk about individuals' ethical deficits, we mean behaviours that are deviations from behaviours desired in an ethical sense, regardless of whether these desirable behaviours are clearly formulated in legal regulations, or in broadly defined ethical programs, for example in ethical codes. Hence, the leading thesis of the considerations made boils down to the statement that the existing ethical deficits in the research behaviour of Polish scientists in the field of social sciences primarily result from the fact that their choices regarding methodological solutions do not usually go hand in hand with in-depth ethical reflection based on ethical disposition, ethical self-awareness and ethical knowledge. As a result, in many research environments, there is a lack of well-established belief that the researcher's ethical competence is an integral component of his professional competences.

However, in the deliberations on the most common deficits and ethical dilemmas occurring during the implementation of scientific research in general, and scientific research in two disciplines - sociology and economics - in particular, the subject of special attention will be the ethical self-awareness of the researcher, entangled in legal and institutional-structural solutions regulating the conduct of scientific research in Poland. An important reason to concentrate on two scientific disciplines - sociology and economics - is not only their interdisciplinary nature but that these are multi-paradigmatic, which causes the majority of methodological dilemmas to become ethical dilemmas. What is more, research conducted within these disciplines generates a number of additional dilemmas of an interpretative nature, which has an impact on the solutions adopted in the broadly understood socio-economic area. However, with a relatively low level of researchers' ethical disposition, these dilemmas are usually limited to methodological dilemmas, often treated in terms of the researcher's high self-awareness and his substantive competences.

An example of the fact that ethical competences are treated more often in terms of substantive competences can be widely accepted, also in other scientific disciplines, the model of universal criteria of Carr's professionalism (1999, pp. 33-46), defined in terms of forms of activity. In these criteria, Carr (1999, p. 34) includes those which:

(1) are important from the point of view of issues and problems occurring in the socio-public field;

(2) require high theoretical competencies as well as practical competencies; 
(3) have an ethical dimension, inscribed in the essence of this activity or profession, requiring a specific articulation in the form of a code of ethics, regulating practical activities;

(4) require certain organizational forms and appropriate regulations established from the perspective of the recruitment and selection of candidates for a given profession or from the perspective of disciplining those who already perform a given profession;

(5) provide a high level of effectiveness of activities within the profession, during which a high level of autonomy of activities related to the independence of ethical judgments.

All the aforementioned criteria of professionalism also apply to people conducting scientific research, hence it can be stated that progress in learning is also the result of compliance with widely understood and quite detailed operationalized ethical standards. The point is that systemic, legal and procedural solutions, concerning practising science, do not generate additional ethical dilemmas for researchers on the one hand, and on the other-do not petrify or even reinforce already existing ethical deficits in the area of science. It would not be reasonable to expect that researchers be compliant with standards formulated within the framework of extensive ethical programs in a situation where legal and institutional solutions lead to a sense of asymmetry in bearing responsibility for dishonestly, tendentiously or even allusively formulated assessments of undertaken or conducted research. This also applies to the assessment of the results of scientific work, scientific achievements, or the use of legal solutions, enabling Polish scientists with degrees and titles obtained outside the country to watch over the quality of teaching at Polish universities and the quality of Polish science, among others, through membership in the Polish Accreditation Committee and the Central Commission for the Academic Degrees and Titles (CKdsSiT). These legal procedures, which have not been done for many years, enabled people who obtained their so-called didactic docentura in Slovakia, i.e. professional titles, being at most the equivalent of a Polish doctorate, receiving the degree of habilitated doctor, entitling them, among others, to provide doctoral programmes. Despite repeated reminders in this matter, they were sent to the Ministry of Science and Higher Education (MNiSW) by the scientific community, including by the Committee on Pedagogical, Sociological and Philosophical Sciences of the Polish Academy of Sciences (PAN), the problem was neglected.

According to the data cited by A. Grabek and C. Bielakowski, in the years 2006-2014 as a result of promotion proceedings in higher education institutions in Slovakia, 142 Polish scientists obtained habilitations and professorship (Grabek \& Bielakowski, 2015, p. 36). As the authors write:

A real habilitation, comparable to the Polish one, is given by the Slovak Academy of Sciences. But so far no Pole has taken advantage of this opportunity. [...] while $[\ldots]$ articles from national magazines published by Poles $[\ldots]$ are treated there as foreign. (2015, p. 35) 
It should be added that in Slovakia there is no obligation to submit a dissertation in the Slovak language for evaluation (a summary in this language is sufficient); instead of a monograph, not only a collection of articles but also an academic or school textbook, methodical work, materials or didactic aids can be submitted and a habilitation colloquium is often held despite the lack of knowledge of the habilitation language by the commission and vice versa, by the habilitationist. ${ }^{2}$ What is more, the Slovak side does not provide access to the conducted doctoral dissertation, which violates not only the principle of open access to scientific achievements as one of the habilitation thesis conditions but also causes Polish scientists to submit their doctoral dissertations (sometimes only slightly modifying the title) as habilitation dissertations. Śliwerski (2012), chairman of the Committee on Pedagogical Sciences of the Polish Academy of Sciences and deputy chairman of the Humanities and Social Sciences section of the CKdsSiT, taking the floor on this matter, stated that:

Guise, fiction and auto-demoralization conquer scientific integrity and honesty, infecting an increasingly numerous group of successive generations of academic teachers, lecturers who want to keep their workplace at all costs, and even get promoted in it $[\ldots]$.

Therefore, it can be stated that the emerging deficits and ethical dilemmas among Polish researchers in the field of social sciences have two basic, but different groups of causes.

The first group of causes refers primarily to the broadly understood ethical deficits, perceived in terms of the unreliability of scientific research, which are mainly related to the structural premises of the functioning of universities and other research units. The indicated structural premises are primarily the emphasis on "productivity" and parameterization as the basic criteria for the assessment of not only scientific units but also scientific employees oriented towards success and individual career. The second group of reasons refers primarily to broadly understood ethical dilemmas; to the ethical context of social research at every stage of the process: conceptualization, selection of methods, techniques and research tools, research (in the case of sociology, this applies especially to classified research, e.g. covert participant observation or focused intelligence), analysis and interpretation of data, and the publication of the developed and interpreted empirical material. An important role is also played by the aforementioned multiparadigmatic character of both economics and sociology, that is the multiplicity of accepted theoretical approaches and the resulting methodological decisions, such as indicators adopted to explain both a given phenomenon or process, and to explain the relationship between two variables, which in the long-term perspective

\footnotetext{
${ }^{2}$ On March 16, 2016, Deputy Prime Minister Jaroslaw Gowin and the Ambassador of Slovakia signed a contract amending the agreement concerning, among others, mutual recognition of the equivalence of documents regarding the awarding of degrees and academic titles. Currently, after 10 years of the previous contract, recognition can no longer apply to the degrees of doctor habilitated and professor (http:// www.nauka.gov.pl/aktualnosci-ministerstwo/nowe-zasady-uznawania-wyksztalcenia-zdobytego-na-slowa cji.html).
} 
prove to be sometimes apparent compounds, and the applied measures have in retrospect a weak predictive power. A classic example can be a problem which currently is so often raised - that of studying the impact of social inequalities not only on the health, mental and social condition of individuals and groups but also on the economic condition. According to Opolski and Potocki $(2010$, p. 8):

$[\ldots]$ there is a clear need to modify the economic measures of the wealth of nations and to supplement them with social, ecological and psychological indicators. [...]. Only then will the instruments that will allow us to reliably and credibly assess the state of wealth in the world be created.

Stodolak, reviewing the most spectacular theoretical findings in the history of economics, which were based on real but badly described and misinterpreted empirical data, refers, among other things, to the thesis of Tabarroka, director of a think-tank, who claims that the research of economists has many serious methodological limitations (2015, p. A11):

Often they rely on too small data samples, they take into account too many irrelevant factors that disrupt the essence of the matter, and omit the key ones. To all this, often the economists themselves, directed not only with noble motives, exaggerate the significance of their work, trying at all costs to prove a predetermined thesis.

\section{The multi-paradigmatic reality of social sciences vs the problems of scientific valuation}

Sociology and economics, two important disciplines within the social sciences, undoubtedly belong to multi-paradigmatic disciplines. This has not only its theoretical-methodological but also ethical consequences, because apart from the multiplicity of validated theoretical approaches, and the multiplicity of methodological approaches (especially in the field of research methods and techniques), there is a multitude of practical uses of scientific knowledge; among others in the area of politics, economy, culture, social communication or shaping public opinion. Thus, the description, diagnosis and interpretation of the social world carried out by sociologists and economists should be referred to the classic postulate by Znaniecki (1934), which has a methodological and ethical character and is defined in terms of the so-called humanistic coefficient. It assumes that the social world is first and foremost the way the respondents see it (the researcher is also part of this world), not the way the researchers see it. And although some research methods and techniques, especially quantitative ones, allow us to preserve the principle that the subjective-objective approach to the subject of research is more often a guiding principle in sociology than in economics, the researcher will not avoid evaluation in the process of made interpretations here either. Max Weber was convinced of this. He recognized this ethical dilemma as the most important problem in sci- 
ence, one that is hard to resolve in the process of undertaking and conducting research. Convinced that in science one will not avoid valuing, Weber postulated that scientific research be guided primarily by honesty and that one should try to reconcile the ethics of belief (acting on values) with the ethics of responsibility (1917/1985, pp. 101-148, 1999, pp. 199-217). Contemporary researchers undertaking this problem, regardless of their beliefs about the possibility and necessity of avoiding valuation in science, agree that this is one of the central problems of science perceived in terms of its primary purpose, that is, the quest for discovering the truth; however, in this pursuit, the researcher cannot be free from the axionormative perspective (cf., among others, Agazzi, 1997; Fisher, 2003, pp. 171-179; Goćkowski \& Pigoń, 1991; Goćkowski, 1996; Heller, 2009; Kleszcz, 2011; Morawski, 2013; Popper, 1997, pp. 137-146). This problem can be clearly seen in experimental psychology or sociology, where, when using certain methods and research techniques (e.g. covert participant observation), the researcher faces a serious dilemma: which good is more important, that of science or of the subject or group being examined.

A second important methodological and ethical directive, resulting from the assumptions of the humanistic coefficient, refers to being especially cautious when introducing significant (systemic) changes based on the results of scientific research and the postulates and expert opinions stemming from them. Scientists, both economists and sociologists, often act as advisers or experts to decisionmaking entities, and although many of them placed solutions which are legitimate from an economic or political point of view in a purely social (group) or human (individual entity) context, this was not always the case. Not everyone was aware of the fact that no social ideology, no economic or political doctrine can be treated as completely true and having no alternative. In recent years, especially in economic theory, a number of leading assumptions have been clearly redefined, mainly under the influence of the criticism aimed at both the neo-liberal perspective in creating the foundations of the socio-economic system and the economic analyses which too often omitted social, cultural, or political contexts. Using a perspective applied in, among others, economic sociology in economic research, usually allows us to diagnose, interpret, and forecast specific phenomena and processes more accurately. However, the use of an interdisciplinary approach in scientific research requires not only knowledge but also the activation of a certain type of social and ethical sensitivity, aimed not only at the perspective of ethical beliefs but also the ethics of responsibility; mainly so that interpretation of individual and/or group motivation or behaviour is largely free from the modifying effect of imposing on them the researcher's value system. With regard to sociological research, it is possible to recall the results of analyses carried out by Dyoniziak (1997, pp. 39-127), which shows that the list of methodological and ethical mistakes made is very long. The present author addressed this subject in another text (cf. Walczak-Duraj, 2016), stressing at the same time that these practices are also used today, although, without systematic research, it is difficult to assess the scale 
of this phenomenon. Hence, speaking about the ethical context of research in social sciences, especially in sociology, we must also take into account the fact that ethical dilemmas can form the basis for unethical choices or behaviours.

Showing the weight of deficits or ethical dilemmas related to research in the social sciences, and especially in sociology, can take place in many different ways. One of them is based on a fairly obvious assumption that every sociological study constitutes an interference in the lives of the respondents, and yet the situation in the researcher-researched relationship is, with some exceptions, fundamentally different from the situation occurring in the individual's relationship with a physician, advocate or a psychologist. Information, opinions or attitudes of respondents, to which a sociologist sometimes tries to reach, are sometimes very intimate, do not directly serve the respondents themselves but are used in an aggregated way, primarily to diagnose and interpret specific phenomena or social processes. This is why not only the methodological self-awareness of the sociologist-researcher is so important, but also their ethical self-awareness, knowledge and ethical sensitivity. A similar statement can be formulated in relation to scientific research conducted in economics, although perhaps the inseparability of the methodological perspective and ethical perspective may not be as common.

\section{Code regulations as an important source of knowledge about dilemmas and ethical deficits in scientific research}

As in the case of any profession dealing with intricate matters, in the profession of a researcher, one may distinguish three basic mechanisms regulating ethical attitudes and behaviours. The first of these is based on internalized values and ethical norms, which makes the ethical disposition and sensitivity of the researcher in many cases a sufficient basis for the ethical standards to be followed by him. The second mechanism consists of various types of legal regulations, ${ }^{3}$ which, as we know, are usually not very effective and, to a greater or lesser extent, susceptible to strategies related to the so-called, getting around the law. The third mechanism, the most extensive one, is paralegal, institutional, most often in the form of official documents in such as various types of ethical programs, in which the principles of good research practice (cf., among others, Ethics Committee in Science at the Presidium of the Polish Academy of Sciences, Ministry of Science and Higher Education, 1994), ethical research guides (cf., among others, Elliott \& Stern, 1997; Nelkin, 1994; Schachman, 1993, pp. 148-149) and ethical codes (cf., among others, Polish Academy of Science, 2012) play a fundamental role.

\footnotetext{
${ }^{3}$ For example, there is a legal obligation to establish ethics committees by institutions (hospitals, universities, etc.) applying for funds to finance research; these commissions analyze research projects primarily in terms of protecting the interests and rights of the respondents (they may request to correct the project or reject it).
} 
A discussion on the validity, prerequisites, and effectiveness of creating such regulations will be omitted here (cf., among others, Błażejewski, 2007; Galewicz, 2009; Grabski, 2000; Hajduk, 2008; Jawłowska, 1994; Shamoo \& Resnik, 2009; Szostek, 2007; Ważny, 2007; Zoll, 2013). Instead, the focus will only be on selected contents contained in these code documents, which are relevant to the present analysis. They show not only the complexity of dilemmas and ethical deficits that arise when conducting scientific research but also their involvement in various legal regulations.

The currently dominating mechanism for setting ethical standards in scientific research, which dates back to the 1970s and 1980s when cases of violation of ethical rules in disciplines of natural sciences and other disciplines began to be identified, functions on two major levels mutually penetrating each other. The first one refers to all situations in which the researcher may experience ethical dilemmas; therefore, all official, written rules/paralegal documents are supposed to shape sensitivity, self-awareness, and ethical knowledge, and thus help them make desired decisions, especially in the context of defining the boundary between freedom and scientific dishonesty which is very often about blurring the boundaries of the social world (not only the limits of freedom, but also of responsibility, rationality, truth, naturalness or privacy), ${ }^{4}$ and in this case mainly about blurring the boundaries of scientific research (the development of Para science, shoddiness, the appearance of scientific research, etc.).

The second plane is all the situations which, although specific, are typical only in relation to broadly understood scientific research (e.g. honesty, objectivity and reliability in evaluating the achievements of other researchers by the reviewer). Here a conscious violation of ethical principles by the researcher seems to be obvious, if only because they are principles resulting from generally accepted principles of social ethics perceived from the perspective of deontological ethics. Here, instead of ethical dilemmas, we speak rather of ethical deficits. The problem is that this distinction is for many people purely analytical and the complexity and relatively low transparency of the research apparatus make it very difficult to estimate the extent to which in economics and sociology we can encounter situations where the researcher not only violates internalized and verbalized ethical standards in the legal or paralegal (good practices, ethical guides, ethical codes, etc.) sense. They also experience certain ethical dilemmas, which-as described earlier-in a nutshell, lead to the aggregate juxtaposition: the good of science vs. the good of the examined person. Therefore, to determine, at least in brief, the significant moments in the crystallization of ethical standards in science one should mention, first and foremost, the groundbreaking document published by the Office of Science and Technology Council in the USA in 1999, describing scientific misconduct as a transgression of ethics in science, consisting in fabrication, falsification, or plagiarism in proposing, performing, or reviewing research, or in reporting research results (leaving the right to the researcher to commit an unintended mistake and the right to express reliable differences in opinions). The

\footnotetext{
${ }^{4}$ I am writing more on this subject in Walczak-Duraj (2016).
} 
operationalisation of the basic concepts of scientific misconduct made in this document and accepted, among others, in the Code of Ethics of a Research Worker from 2012 prepared by the Committee on Ethics in Science, allows us to develop in fairly standardized way regulations relating to specific fields and disciplines.

Thus, fabrication means the preparation, recording, and publication of results not obtained; falsification is the manipulation of the research material, equipment, or method, and the replacement or omission of experimental data in such a way that the test results are not truly presented in the reports, while plagiarism means the appropriation of other people's ideas, methods, results or descriptions without proper reference. It is worth emphasizing that plagiarism also involves unauthorized use of information obtained during a confidential review of applications and manuscripts; plagiarism can also pertain to, for example, unauthorized use of conference presentations by other researchers. Taking into account the rather common obligatory nature of checking bachelor's, master's and doctoral theses in the anti-plagiarism system, it can be said that it is not only in the public perception that we observe so much attention paid to plagiarism rather than the dishonesty of inventing and falsifying research results. Perhaps because it is relatively easy to identify such practices and because of the fact that in Poland there are two different but interwoven model rules of conduct in the case of scientific dishonesty - the issues are left in the competence of individual institutions as well as transferred to the level of competence of state institutions such as the Ministry of Science and Higher Education, CKDSSiT, or the National Science Center (NCN).

Here, one should mention another milestone: the introduction of the European Charter for Researchers in Poland, with its principles developed in 2005 by the European Commission. The document defined, at least in a formal sense, rules of conduct for the recruitment of researchers to create an attractive, open, and sustainable European labour market for scientists. However, open competitions for positions in science also stir criticism, not only because of situations in which the determination of qualification requirements is tailored for a "chosen" candidate, but also, for example, due to the fact that it is possible to break the master-student relationship, which may also generate ethical dilemmas in the promoters of completed PhDs.

If one assumes that the principles of good practices developed so far in Poland may constitute a kind of benchmark, then it can be said that they are more or less violated, and some are violated intentionally, with neither remorse nor responsibility for these violations. As suspected, adherence to the principles of scientific work should be based on adequacy and standardization of methods; meticulous documentation of results; skepticism towards the obtained results; honest recognition of the due participation of colleagues, competitors and predecessors; honest assessment of others; proper management and cooperation in scientific teams; taking into account the needs of young researchers; observing the principles of authorship of scientific publications (where the minimum co-authorship criterion is participation in the creation of the research concept, implementation of research, its interpretation, or preparation of publications in the area of co-author specialties) and avoiding conflicts of interest, also within one's own scientific 
work (Ethics in Science team at the Minister of Science, 2004, pp. 5-9). This remark also applies to regulations regarding good practices in reviewing procedures in science, announced in 2011 by the Ministry of Science and Higher Education. It seems that currently the majority of comments, coming mainly from young scientists, are precisely related to this area of scientific activity where purely substantive standards are interwoven with ethical standards. Here, the expectations regarding the observance of good practices relate to both the duties of the contracting entity and the recipient of the review (the right choice of reviewers, their contracts, the independence of reviewers' opinions, the conflict of interest in the reviewing process, remuneration for preparing the review, confidentiality of review procedures, situations of conflict in the reviewing process - assigning additional reviewers, problems and abuses in reviewing processes), as well as the duties of the reviewers themselves their appropriate competencies, their reactions in situations of conflict between parties in the reviewing process, performing formal duties by the reviewers, their honesty and diligence in preparing the reviews, cohesiveness and concreteness of the review-its conclusions should be clear and unequivocal, their conscientiousness and confidentiality-reviews should be prepared on time and without consulting other reviewers).

Unfortunately, long yet unstructured observations regarding reviewing practices allow us to state that they are currently a serious problem in Polish science. It is aggravated by the fact that code regulations or other official documents of institutional nature on good practices appear also in specific institutions distributing public funding to various types of research grants.

A good example of it is the National Science Centre (NCN), which formulated its recommendations for research involving people in April 2016. ${ }^{5}$ The recommendations were based on two fundamental premises concerning ensuring compliance of conducted research with high ethical standards and the willingness to support researchers in resolving ethical dilemmas related to designing and conducting research. The document also explicitly defined specific premises for implementing such recommendations: promoting the implementation of high-quality research published in international publishing houses, compliant with ethical standards; respect for the dignity of the human being and its fundamental rights and freedoms (narrowed in the current legal regulations only to a certain group of tests), as well as the obligation to obtain the consent or opinions of the commissions assessing the ethical aspects of research. The recommendations of the NCN Council concern all types of research, in all areas, fields, and disciplines in which research is conducted with humans. It should be acknowledged that this document, in terms of protecting the rights of persons participating in the study, clearly goes beyond the obligations and duties contained in Code of Sociology Profession of 2012 (www.pts.org.pl/public/upload/kodeks.pdf).

\footnotetext{
${ }^{5}$ The NCN (National Science Centre) Council at the same time asks scientific units and other entities applying for NCN grants to appoint in these entities the commission for research ethics (https://www.ncn.gov.pl/sites/default/files/pliki/2016_zalecenia_Rady_NCN_dot_etyki_badan.pdf).
} 


\section{Conclusions}

At the starting point of these considerations, the thesis was formulated that the existing ethical deficits in research behaviour of Polish scientists in the field of social sciences stem primarily from the fact that their choices referring to methodological solutions do not usually go hand in hand with deep ethical reflection based on their ethical disposition, ethical self-awareness, and ethical knowledge. The ideas presented here seem to confirm this thesis. Therefore, it can be assumed that the observed processes of institutionalization of ethical standards in science will not bring desirable effects related to reliability, integrity, and transparency of scientific research as long as the majority of researchers in social sciences (including sociology and economics) will not realise that the researcher's ethical competence is an integral component of substantive competences. Otherwise, more and more often in the area of scientific journalism, but not only there, we will come across theses formulated especially by young scientists claiming that in Poland the system in which science is practised is bad and degenerates science. This, in turn, leads to a conclusion that being a good scientist and a decent person is rare and difficult (Suchodolska \& Kulesza, 2016). It means that blunders of an ethical or even legal nature have no major impact not only on the individual's scientific position but also on its social position. Perhaps this is because the category of honour is increasingly confused with the category of honorarium. The existing ethical deficits among Polish scientists are deepened by the processes taking place in the area of didactics. According to Wilkin's report (http://www.krasp.org.pl/pl/ archiwum_prezydia/archiwum_prezydia), there is a sharp rivalry for students between public and non-public universities, and between the departments of the same public institution. Unfortunately, this competition is not only fierce, but is often based on unlawful activities (cf. Pasztelańska, 2016, pp. A12-13).

It should, therefore, be concluded that both approaches to ethics of scientific research (dilemmas and ethical deficits) must be referred to legal and procedural solutions, including the rules of functioning of scientific and research institutions, universities, or other higher education institutions. Even the most rigorous codes and regulations will not bring the expected result if, in the scientific community, especially among novice researchers, solutions to disseminate knowledge about these regulations are not insisted. It is crucial that these are disseminated in a way that beliefs about the negative consequences of the destruction of normativity in science become the leading basis for accepting the thesis that ethical competence in science is an attribute characteristic of substantive competences. 


\section{References}

Agazzi, E. (1997). Dobro, zło i nauka. Etyczny wymiar działalności naukowo-technicznej (E. Kałuszyńska, Trans.). Warszawa: Oficyna Akademicka OAK.

Błażejewski, J. (Ed.) (2007). Etyka w edukacji, nauce, polityce i biznesie. Gdańsk: Gdańskie Towarzystwo Naukowe.

Carr, D. (1999). Professional education and professional ethics. Journal of Applied Philosophy, 16(1), 33-46.

Dyoniziak, R. (1997). Sondaże a manipulowanie społeczeństwem. Kraków: Universitas.

Elliot, D., \& Stern, J. E. (Eds.) (1997). Research ethics. A reader. Lebanon: University Press of New England.

Ethics in Science Team at the Minister of Science. (2004, May 25). Dobra praktyka badań naukowych. Rekomendacje. http://www.uwm.edu.pl/wnt/sites/default/files/uploads/ studenci/pliki/dobra-praktyka.pdf

Etyka $i$ patologie polskiego środowiska akademickiego. (n.d.). https://ntaetyka. cordpress.com/category/aspekty-finanse/page3/

Fisher, C. (2003). Developing a code for academics. Science and engineering Ethics, 9(2), $171-179$.

Galewicz, W. (2009). O etyce badań naukowych. Diametros, 19, 48-57.

Goćkowski, J. (1996). Ethos nauki i role uczonych. Cracow: Wydawnictwo Secesja.

Goćkowski, J., \& Pigoń, K. (1991). Etyka zawodowa ludzi nauki. Wrocław-WarszawaKraków: Wydawnictwo Polskiej Akademii Nauk.

Grabek, A., \& Bielakowski, C. (2015). Naród, turystyka habilitacyjna. Wprost, August 9.

Grabski, M. W. (2000). Dobra praktyka naukowa. Warszawa: The Ethics in Science team at the Chair of the State Committee for Scientific Research. http://kbn.icm.edu.pl/ etyka/praktyka.html

Hajduk, Z. (2008). Nauka a wartość, aksjologia nauki. Lublin: Towarzystwo Naukowe KUL.

Heller, H. (2009). Jak być uczonym. Kraków: Wydawnictwo Znak.

Jawłowska, A. (1994). Życie i kodeksy. Etyka, 27.

Kleszcz, R. (2011). Nauczyciel akademicki: neutralność czy aksjologiczne zaangażowanie. Etyka, 44, 79-96.

Kopka, J. (2000). Społeczny wymiar postrzegania moralnego. Studium socjologiczne. Łódź: Wydawnictwo Uniwersytetu Łódzkiego.

Liberkowski, R. (2009). Fenomen wyobrażeń. Poznań: Adam Mickiewicz University Press.

Ministry of Science and Higher Education. (2011). Dobre praktyki $w$ procedurach recenzyjnych $w$ nauce. Warsaw. http://www.nauka.gov.pl/g2/oryginal/2014_02/30 7f933b1a75d6705a4406d5452d6dbf.pdf

Morawski, Z. R. (2013). Etyczne aspekty działalności badawczej w naukach empirycznych. Warszawa: Wydawnictwo Uniwersytetu Warszawskiego.

Nelkin, D. (1994). Forbidden research: limits to inquiry in the social sciences. In E. Erwin, S. Gendin, \& L. Kleinman (Eds.), Ethical issues in scientific research. An anthology. New York \& London: Garland Publishing. 
Opolski, K., \& Potocki, T. (2010). Sposoby pomiaru bogactwa narodów w obliczu zmieniającego się otoczenia ekonomiczno-społecznego świata. e-Finanse, 6(3), 1-10. www.e-finanse.com

Pasztelańska, J. (2016). Wyższe szkoły pobierania czesnego. Dziennik. Gazeta Prawna, 73(4220), April 15-17.

The Polish Academy of Sciences. (1994). Dobre obyczaje w nauce. Warszawa: Ethics Committee in Science at the Presidium of the Polish Academy of Sciences.

The Polish Academy of Sciences. (2012, December 13). Kodeks etyki pracownika naukowego, Annex to Resolution No. 10/2012 General Assembly of the PAS of December 13, 2012. Warszawa: Ethics Committee in Science. http://www.nauka.gov.p1/g2/ oryginal/2014_02/2ae2188ff8670eed98ede50de1e 9007f.pdf

Popper, K. R. (1997). Odpowiedzialność moralna uczonego. In K. R. Popper, Mit schematu pojęciowego. W obronie nauki i racjonalności (B. Chwedeńczuk, Trans.). Warszawa: Książka i Wiedza.

Proposed Federal Policy on Research Misconduct. (1999). www.aps.org/policy/statements/ federalpolicy.cfm

Reykowski, J. (1990). Ukryte założenia normatywne jako osiowy składnik mentalności. In J. Reykowski, K. Skarżyńska, M. Ziółkowski (Eds.), Orientacje społeczne jako element mentalności. Poznań: Publishing House „Nakom”.

Schachman, H. K. (1993). What is misconduct in science? Science, 261, 148-149.

Scheler, M. (1977). Ressentiment (J. Garewicz, Trans.). Warszawa: Czytelnik.

Shamoo, A., \& Resnik, D. (2009). Responsible conduct of research $\left(2^{\text {nd }}\right.$ Ed.). New York: Oxford University Press.

Stodolak, S. (2015). Kompromitacja nie tylko dawnej ekonomii. Dziennik. Gazeta Prawna, 30(3923), February 13-15.

Suchodolska, M., \& Kulesza, K. (2016). Polska nauka na krześle elektrycznym. Dziennik. Gazeta Prawna, 73(4220), April 15-17.

Szostek, A. (2007). Czy potrzebny jest kodeks. Dobre praktyki w szkołach wyższych? Nauka, 2, 45-55.

Śliwerski, B. (2012). Banalizacja nauki. Forum Akademickie, 4. https:/forumakademickie. $\mathrm{pl} / \mathrm{fa} / 2012 / 04 /$ banalizacja-nauki/

Walczak, A. (2010). (Samo)świadomość - w kierunku dojrzałości etycznej nauczyciela. In M. Michalak (Ed.), Etyka i profesjonalizm w zawodzie nauczyciela. Łódź: Wydawnictwo Uniwersytetu Łódzkiego.

Walczak-Duraj, D. (2016). Niepewność i ryzyko jako główne ramy interpretacyjne współczesnych społeczeństw. Humanizacja Pracy, 1(283).

Walczak-Duraj, D. (2016, April 22). Miejsce kompetencji humanistycznych i dyspozycji etycznych $w$ treściach ksztatcenia polskich socjologów (a paper presented at a scientific conference titled: „Socjolog, czyli kto?... Problemy kwalifikacji socjologów i ich pozycja na rynku pracy”). Katowice.

Walczak-Duraj, D. (2017). Przyczyny deficytów i dylematów etycznych w badaniach naukowych. Annales. Ethics in Economic Life, 20(1), 17-32.

Ważny, J. (2007). Etyka w pracach naukowych. Forum Akademickie, 5, https://prenumeruj.forumakademickie.pl/fa/2007/05/etyka-w-pracach-naukowych/ 
Weber, M. (1985). Sens „wolnej od wartościowań” socjologii i ekonomii. In A. Chmielecki, S. Czerniak, J. Niżnik, \& S. Rainko (Eds.), Problemy socjologii wiedzy. Warszawa: Państwowe Wydawnictwo Naukowe.

Weber, M. (1999). Nauka jako zawód i powołanie (P. Dybel, Trans.). In Z. Krasnodębski (Ed.), M. Weber. Warszawa: Wiedza Powszechna.

Woźnicki, J. (Ed.) (2015). Program rozwoju szkolnictwa wyższego do 2020 r. Opis prac nad programem rozwoju szkolnictwa wyższego do 2020 r. i jego najważniejsze elementy, Part I. Warszawa.

Znaniecki, F. (1934). The method of sociology. New York: Farrar \& Rinehart, Inc.

Zoll, A. (2013). Komentarz do kodeksu etyki naukowca. Forum Akademickie, 1. https://prenumeruj.forumakademickie.pl/fa/2013/01/kronika-wydarzen/kodeks-etyki-naukowca/\#

http://ec.europa.eu/euraxess/pdf/brochure_rights/kina21620b8c_pl.pdf

http://www.krasp.org.pl/pl/archiwum_prezydia/archiwum_prezydia

http://www.nauka.gov.pl/aktualnosci-ministerstwo/nowe-zasady-uznawania-wyksztalceniazdobytego-na-slowacji.html

https://www.ncn.gov.pl/sites/default/files/pliki/2016_zalecenia_Rady_NCN_dot_etyki_bad an.pdf

www.pts.org.pl/public/upload/kodeks.pdf 